\title{
Growth of ornamental sunflowers in two growing seasons under semiarid conditions
}

\author{
Sheila Daniella Pereira da Silva ${ }^{1 *}$, Márkilla Zunete Beckmann-Cavalcante ${ }^{2}$, Gracielle Peixoto de Souza ${ }^{3}$, \\ Thais Silva de Oliveira ${ }^{3}$, Raylla da Rocha Lima ${ }^{3}$, Agnaldo Rodrigues de Melo Chaves ${ }^{4}$ \\ ${ }^{1}$ Federal University of São Francisco Valley, Agricultural Sciences Campus, 56300-990, Petrolina, PE, Brazil. E-mail: sheiladps@outlook. \\ com, ${ }^{2}$ Collegiate of Agronomic Engineering, Federal University of São Francisco Valley, Agricultural Sciences Campus, 56300-990, Petrolina, \\ PE, Brazil, ${ }^{3}$ Federal University of São Francisco Valley, Agricultural Sciences Campus, 56300-990, Petrolina, PE, Brazil, ${ }^{4}$ Laboratory of Plant \\ Physiology, Embrapa Semiárido, 56302-970, Petrolina, PE, Brazil
}

\section{A B S T R A C T}

\begin{abstract}
Sunflower is considered a temperate zone crop but it can perform well under varying climate conditions. In this context, the aim of this study was to evaluate the growth of ornamental sunflower cultivars for cutting in two growing seasons in semiarid conditions. Sunflowers cultivars were sown in a randomized complete design in a split plot system, with four blocks. Six cultivars were evaluated ('Bonito de outono sortido', 'Sol noturno', 'Sol vermelho', 'Jardim amarelo alto', 'Sunflower F1 sunbright supreme' and 'Sunflower F1 vincents choice') in the main plots and two growing seasons in the subplots (GS1 - hot weather and GS2 - mild weather). Plant emergence percentage, plant height, stem diameter, number of leaves and internal inflorescence diameter were significant affected both by sunflowers cultivars and growing seasons. Emergence speed index and external inflorescence diameter were significantly affected by the interaction of cultivars and growing seasons. The obtained results indicated 'Sol vermelho' for cultivation in growing seasons with mild temperatures (GS2) and 'Sunflower F1 vincents choice' recommended for both growing seasons with mild climatic (GS2) and in warmer conditions (GS1). Although all other cultivars studied have not been indicated immediately, they may be considered for cultivation, but more studies are necessary for better acclimatization.
\end{abstract}

Keywords: Adaptation; Varietal performance; Cut flowers; Helianthus annuus L

\section{INTRODUCTION}

Around the word, the floriculture contributes significantly to the agricultural economy, is highly competitive and dynamic moving billions of dollars annually (Newman, 2011). The commercial floriculture, understood as the professional and business activity of production, commerce and distribution of flowers and plants cultivated for ornamental purposes, represents one of the most promising segments of contemporary Brazilian agribusiness (Junqueira and Peetz, 2017). But according these authors, the national floricultural activity is not homogeneous. On the contrary, there are immense disparities and technological systems of cultivation and commercialization, varying according to macro-regional areas and vocations, segments (cut, vase, landscaping and gardening), climatic and ecological conditions (tropical, subtropical, temperate), business culture and socioeconomic level of producers, dynamics and potentials of consumer markets.
In the context of innovation and diversification of Brazilian flowers market, the sunflower (Helianthus annuиs L.) is a crop that has been gaining expression in the field due to the development of cultivars specifically for this purpose, providing variety of colours and formats (Nascimento et al., 2016), in order to meet the most varied consumer preferences. The sunflower crops offers as advantages: short cycle, providing quick return on investment to the producer, ease of propagation and management, high photosynthetic efficiency and possibility to be cultivated under different conditions of latitude, longitude and photoperiod (Berglund, 2007; Curti et al., 2012). In general, it could be said that sunflower is among the most cosmopolitan crops and highly adapted to diverse environments (Beard and Geng, 1982; Zaidi et al., 2012). Considering these characteristics it is suggested that ornamental sunflower has conditions to be cultivated in semiarid regions because tolerates well high temperatures and light availability, since supplied with water and

\footnotetext{
*Corresponding author:

Sheila Daniella Pereira da Silva. Federal University of São Francisco Valley, Agricultural Sciences Campus, 56300-990, Petrolina, PE, Brazil.

E-mail: sheiladps@outlook.com

Received: 14 December 2017; $\quad$ Accepted: 28 April 2018
} 
nutritional needs (Coutinho et al., 2015). Crop yield is influenced by genetics features of each variety and by weather conditions of the region at different seasons of the year, as well as the interaction between these factors (Aguirrezábal et al., 2003; Porto et al., 2007; Izquierdo et al., 2009; Balalić et al., 2012; Papatheohari et al., 2016).

Studies are necessary to investigate the agronomic performance of ornamental sunflower in order to indicate adapted cultivars and ideal sowing periods, increasing the chances for crop successfull establischment. According to Papatheohari et al. (2016) this is important, especially in agricultural situations and regions where the crop is not common or widely adopted by the farmers.

Therefore, the aim of the present study was to evaluate the growth of ornamental sunflower cultivars in two growing seasons cultivated under semiarid conditions.

\section{MATERIAL AND METHODS}

\section{Experimental area description}

The study was carried out during the years of 2015 and 2016 on the experimental Floriculture farm of Federal University of São Francisco Valley (UNIVASF), Petrolina County, Brazil, at the sub medium region of São Francisco River, whose geographic coordinates are $09^{\circ} 21^{\prime}$ south latitude and $40^{\circ} 34^{\prime}$ west longitude. According to Köppen's climate classification (Alvares et al., 2014), the region is classified as BSh (dry, semi-arid and with low latitude and altitude; a dry period of nine months and rainfall concentrated from February to April), where the annual rainfall is less than $500 \mathrm{~mm}$ and mean annual temperature is slightly higher than $26.5^{\circ} \mathrm{C}$. Throughout the cultivation, temperature (minimum and maximum), air moisture (minimum and maximum), global solar radiation and precipitation data were recorded in climatological station located near experimental area (Table 1).

\section{Experimental design and cultivars}

The experimental design was in a randomized complete block desing in a split plot arrangement, with six plots, two subplots and four blocks. Six cultivars were evaluated in plots: 'Bonito de outono sortido, 'Sol noturno', 'Sol vermelho', 'Jardim amarelo alto', 'Sunflower F1 sunbright supreme' and 'Sunflower F1 vincents choice'. In the subplots, two growing seasons, being growing season 1
(GS1), from October 14 to December 10, 2015 (featured by hot weather with high temperatures, low relative humidity, lack of rain and high luminous availability) and growing season 2 (GS2), from March 22 to May 14, 2016 (comprised a period of mild climatic conditions, with lower temperatures, higher air relative humidity, with rainfall and greater cloudiness). Cultivation season have been chosen based on the climatological historical series for the region (Inmet, 2016).

The cultivars evaluated were 'Bonito de outono sortido' (Isla, multiple inflorescences variety, petal colours - yellow/ red, crop cycle - 70 days, plant height - 2.0 to $2.5 \mathrm{~m}$ and inflorescence diameter - 10 a $15 \mathrm{~cm}$ ), 'Sol noturno' and 'Sol vermelho (Isla, multiple inflorescences varieties, crop cycle - 70 days, petal colours - purple/orange with dark flower disk, plant height -2.0 to $3.0 \mathrm{~m}$, inflorescence diameter - 15.0 to $18.0 \mathrm{~cm}$ ), 'Jardim amarelo alto' (Isla, variety, one-inflorescence stem, petal colours - yellow, crop cycle - 60.0 days, plant height -70.0 to $90.0 \mathrm{~cm}$ and inflorescence diameter - 18.0 to $24.0 \mathrm{~cm}$ ), 'Sunflower F1 sunbright supreme' and 'Sunflower F1 vincents choice' (Sakata, hybrid cultivars, one-inflorescence stems, pollen less, petal colours - yellow with brown flower disk, crop cycle -50.0 to 75.0 days, plant height -1.0 to $1.5 \mathrm{~m}$ ). These sunflower cultivars are among the most commercial in Brazil but with no tradition of cultivation in the studied region.

\section{Experimental details}

The soil was classified as Psamment (Soil Survey Staff, 2014) and it presented the following physical characteristics:

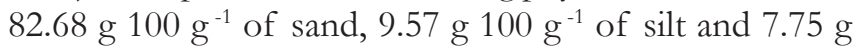

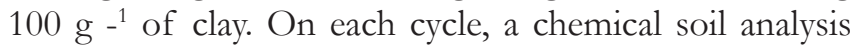
was carried out (Table 2) and the foundation fertilization was performed two days before sowing, applying $500.0 \mathrm{~kg}$ $\mathrm{ha}^{-1}$ of NPK 6-24-12 for GS1 and $333.0 \mathrm{~kg} \mathrm{ha}^{-1}$ of the same formulation for GS2, as recommended by Ribeiro et al. (1999). For GS1 the amount of fertilizer applied was higher due to the field trial was never used before (freshly deforested) and for GS2 was not necessary the same amount of fertilizer due to the residual effect of the first season.

E.C. $=$ Electrical conductivity; $\mathrm{Ca}^{2+}=$ Calcium; $\mathrm{Mg}^{2+}=$ Magnesium; $\mathrm{Na}^{+}=$Sodium; $\mathrm{K}^{+}=$Potassium; $\mathrm{SB}=$ Sum of basis $\left(\mathrm{Ca}^{2+}+\mathrm{Mg}^{2+}+\mathrm{K}^{+}+\mathrm{Na}^{+}\right) ; \mathrm{H}+\mathrm{AL}=$ Potential acidity

Table 1: Mean temperature, air moisture, global solar radiation and rainfall during the field experiments in growing season one (GS1) and growing season two (GS2)

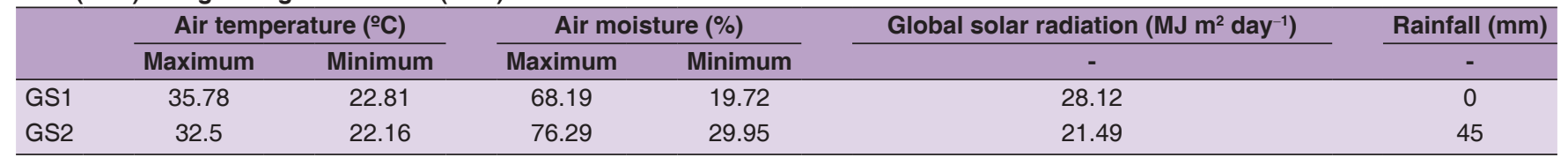


Silva, et al.

Table 2: Chemical soil composition of the experimental area in the $0-20 \mathrm{~cm}$ layer in growing season 1 (GS1) and in growing season 2 (GS2)

\begin{tabular}{|c|c|c|c|c|c|c|c|c|c|c|c|c|}
\hline \multirow[t]{2}{*}{ 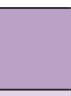 } & $\mathrm{pH}\left(1: 2.5 \mathrm{H}_{2} \mathrm{O}\right)$ & E.C/25으 $\left(\mathrm{dS} \mathrm{m}^{-1}\right)$ & $\mathrm{Ca}^{2+}$ & $\mathrm{Mg}^{2+}$ & $\mathbf{K}^{+}$ & $S_{b}$ & $\mathrm{H}+\mathrm{Al}$ & $T$ & $\mathrm{Al}^{3+}$ & \multirow[t]{2}{*}{ V (\%) } & \multirow[t]{2}{*}{$\mathrm{P}\left(\mathrm{mg} \mathrm{dm}^{-3}\right)$} & \multirow[t]{2}{*}{ O.M. (\%) } \\
\hline & \multicolumn{9}{|c|}{$\left(\mathrm{cmol}_{\mathrm{c}} \mathrm{dm}^{-3}\right)$} & & & \\
\hline GS1 & 5.90 & 0.60 & 2.20 & 1.40 & 0.74 & 4.50 & 1.82 & 6.31 & 0.00 & 71.00 & 94.68 & 1.61 \\
\hline GS2 & 5.80 & 0.11 & 1.80 & 1.00 & 0.38 & 3.21 & 1.98 & 5.19 & 0.00 & 62.00 & 55.55 & 2.00 \\
\hline
\end{tabular}

E.C. $=$ Electrical conductivity; $\mathrm{Ca}^{2+}=$ Calcium; $\mathrm{Mg}^{2+}=$ Magnesium; $\mathrm{Na}^{+}=$Sodium; $\mathrm{K}^{+}=$Potassium; $\mathrm{SB}=\mathrm{Sum}$ of basis $\left(\mathrm{Ca}^{2+}+\mathrm{Mg}^{2+}+\mathrm{K}^{+}+\mathrm{Na}^{+}\right) ; \mathrm{H}_{+} \mathrm{AL}=\mathrm{Potential}$ acidity in $\mathrm{pH}$ 7.0; $\mathrm{T}=$ Cation-exchange capacity in $\mathrm{pH} 7.0 ; \mathrm{Al}^{3+}=$ Exchangeable acidity; $\mathrm{V}=$ Saturation for basis; $\mathrm{P}=\mathrm{Available} \mathrm{phosphorus} \mathrm{e} \mathrm{O.M.=} \mathrm{Organic} \mathrm{matter.}$

in $\mathrm{pH}$ 7.0; $\mathrm{T}=$ Cation-exchange capacity in $\mathrm{pH} 7.0 ; \mathrm{Al}^{3+}=$ Exchangeable acidity; $\mathrm{V}=$ Saturation for basis; $\mathrm{P}=$ Available phosphorus e O.M.= Organic matter.

The experimental area presented $206.59 \mathrm{~m}^{2}(7.3 \times 28.3 \mathrm{~m})$, composed of 24 beds (plots) measuring each one $4.3 \mathrm{x}$ $1.3 \mathrm{~m}$. Each plot contained four planting row spaced $0.3 \mathrm{~m}$, where only the two central rows were considered as useful area for evaluations. For sowing, there were used seeds of the same commercial lot, purchased from specialized companies, for each cultivar. A direct seeding was carried out, with one seed per planting hole about $2 \mathrm{~cm}$ deep, with a spacing of $0.3 \mathrm{~m}$ between rows and $0.3 \mathrm{~m}$ between plants.

Irrigation was performed early in the morning and daily through a drip system arranged in the same crop spacing, irrigating all plots simultaneously. The irrigation time was one hour day ${ }^{-1}$, with a mean drip flow of $0.9 \mathrm{~L} \mathrm{~h}^{-1}$ and a total daily irrigation depth of approximately $9 \mathrm{~mm}$. During GS1, from the fourth week of cultivation, due to the higher water demand of the crop, the frequency of irrigation was increased to twice a day, one hour in the morning and one hour in the afternoon, comprising $18 \mathrm{~mm}$ per day, and a total of $792 \mathrm{~mm}$ per cycle. At GS2, the total irrigation depth was only $477 \mathrm{~mm}$.

During the reproductive stage, the cultivars with multiple inflorescences were managed by removing the axillary or lateral buds, leaving only the apical bloom to obtain oneinflorescence stems (Andrade et al., 2012).

\section{Measurements}

First, a germination test was carried out in laboratory conditions to verify the potential seed germination (Brasil, 2009). The seeds used in this analysis were from the same lot which were sown on the field experiment. In the field, after sowing were evaluated: plant emergence percentage (visualized through cotyledons and counted daily until stabilization) and emergency speed index (ESI), adapted from Maguire (1962) $\left[\mathrm{ESI}=\left(\mathrm{E}_{1} / \mathrm{N}_{1}\right)+\left(\mathrm{E}_{2} / \mathrm{N}_{2}\right)+\ldots+\right.$ $\left(\mathrm{E}_{\mathrm{n}} / \mathrm{N}_{\mathrm{n}}\right)$, which $\mathrm{E}_{1}, \mathrm{E}_{2}$ and $\mathrm{E}_{\mathrm{n}}$ correspond to the number of seedlings emerged at the first, second and last count, respectively, and $\mathrm{N}_{1}, \mathrm{~N}_{2}$ and $\mathrm{N}_{\mathrm{n}}$ represent the number of days elapsed until the first, second and last count, respectively.
The evaluation was performed when the plants were in phenological stage R5.5, which means 50\% of the disc flowers open (Berglund, 2007). The measurements were carried out in three plants from each plot, chosen randomly to obtain the representative average. The plant height $(\mathrm{H})(\mathrm{cm})$ was measured from ground level to the inflorescence insertion. For stem diameter (SD) ( $\mathrm{mm})$ a

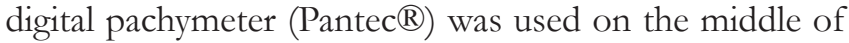
the stem, and counted the number of leaves per plant (NL). The flowering measurements was performed from the internal inflorescence diameter (IID) and external inflorescence diameter (EID) ( $\mathrm{mm})$, using a digital pachymeter considering for both the largest diameter. For IID was considered the ends of the disc flowers and for EID, the terminal ends of the ray flowers.

\section{Statistical analysis}

The data were submitted to analysis of variance (ANOVA) to diagnose significant effect by the $\mathrm{F}$ test $(\phi<0.05)$. Seedling emergence results were transformed by arc sen $V_{x} / 100$ function to meet the basic assumptions of statistics. The average comparison was performed by Scott-Knott test. Pearson's linear correlation test was performed $(p<0.01)$ among the variables of height, stem diameter and leaf number. All statistical analysis was performed using the Assistat v. 7.7 software (Silva and Azevedo, 2016) and graphs by using the Sigmaplot v. 10.0 software (Systat Software, Inc, Germany).

\section{RESULTS AND DISCUSSION}

\section{Plant emergence}

The plant emergence began on the third day and was completed within 9 days after sowing in GS1 and 10 days in GS2, within the limits reported for the crop (Rodrigues et al., 2012; Papatheohari et al., 2016). The analysis of variance revealed that percentage of emergence was influenced by cultivars and growing seasons, but with no interaction between them (Table 3). Among the evaluated cultivars, 'Sunflower F1 vincents choice' exhibits statistically the higher plant emergence percentage. Plant emergence is directly related to seed quality and environment adaptability. Its performance varies among cultivars and depends on the physiological potential of each genotype (Bewley et al., 2013). 
The higher plant emergence percentage was observed on the GS1, although it was expected to be higher on the GS2, since climatic conditions were milder and have influence on the soil temperature, and consequently, the germination process. However, on the GS2, there was occurrence of caterpillars (Agrotis ipsilon Hufnagel) in the field that might have contributed to reduction in seedling emergence percentage, considered only when the cotyledons were exposed. Although the plant emergence percentage was higher on the GS1, in general it was low considering the germination potential indicated by the seed companies ( 71.0 to $98.0 \%$ ), but the test carried out in laboratory conditions showed that seeds of all cultivars used were superior to $71 \%$ of germination (Table 4 ). This result indicates the high potential of seed germination when humidity and temperature are controlled. For sunflower 'Catissol 01' the germination in the field (55\%) was reduced when compared to results of germination in laboratory (76.0\%) (Rocha et al., 2015). Different from laboratory controlled conditions, emergence of seedlings from the soil in open field depends on a range of environmental factors of which water and temperature are the most important (Bewley et al., 2013).

Regarding to emergency speed index (ESI) there was a significant effect of interaction between cultivars and growing season (Table 2). There was observed that GS1 (Fig. 1) had a similar influence on all evaluated cultivars, with ESI varying from 7.72 to 10.66. In GS2, 'Sunflower F1 vincents choice' was statistically superior $(\mathrm{ESI}=11.54)$ and
Table 3: Analysis of variance for sunflower cultivars and growing seasons effects on plant emergence percentage (PEP) and emergence speed index (ESI)

\begin{tabular}{lcc}
\hline Source of variation & PEP (\%) & ESI \\
\hline Blocks & $0.98^{\mathrm{ns}}$ & $1.52^{\mathrm{ns}}$ \\
Cultivars (C) & $5.95^{\star *}$ & $9.44^{\star *}$ \\
'Bonito de outono sortido' & $43.76^{\mathrm{b}}$ & $5.76^{\mathrm{c}}$ \\
'Sol noturno' & $52.68^{\mathrm{b}}$ & $8.38^{\mathrm{b}}$ \\
'Sol vermelho' & $50.09^{\mathrm{b}}$ & $7.49^{\mathrm{b}}$ \\
'Jardim amarelo alto' & $48.94^{\mathrm{b}}$ & $8.51^{\mathrm{b}}$ \\
'Sunflower F1 sunbright supreme' & $47.41^{\mathrm{b}}$ & $6.93^{\mathrm{c}}$ \\
'Sunflower F1 vincents choice' & $61.06^{\mathrm{a}}$ & $11.10^{\mathrm{a}}$ \\
C.V. (\%) (C) & 13.49 & 20.79 \\
Growing seasons (GS) & $98.08^{\star *}$ & $26.73^{* *}$ \\
GS1 & $59.62^{\mathrm{a}}$ & $9.04^{\mathrm{a}}$ \\
GS2 & $41.69^{\mathrm{b}}$ & $7.01^{\mathrm{b}}$ \\
C.V. (\%) (GS) & 12.70 & 16.98 \\
Interaction C x GS & $1.32^{\text {ns }}$ & $3.18^{*}$
\end{tabular}

** and * significant at $1 \%$ and $5 \%$ of probability by the $\mathrm{F}$ test, respectively; ns = non-significant; C.V. $=$ coefficient of

variation. Means followed by the same letter in the column do not differ by Scott-Knott's test at $5 \%$ probability.

Table 4: Analysis of variance for sunflower cultivars on germination percentage in controlled conditions

\begin{tabular}{lc}
\hline Source of variation & Germination (\%) \\
\hline Cultivars & $6,20^{* *}$ \\
'Bonito de outono sortido' & $87^{\mathrm{b}}$ \\
'Sol noturno' & $80^{\mathrm{b}}$ \\
'Sol vermelho' & $75^{\mathrm{b}}$ \\
'Jardim amarelo alto' & $96^{\mathrm{a}}$ \\
'Sunflower F1 sunbright supreme' & $89^{\mathrm{b}}$ \\
'Sunflower F1 vincents choice' & $99^{\mathrm{a}}$ \\
C.V. (\%) & 9,11 \\
\hline ** significant at 1\% of probability by the F test, respectively; ns = non-significant; c.V. = coefficient of variation. Means
\end{tabular}

** significant at $1 \%$ of probability by the $F$ test, respectively; $n \mathrm{n}=$ non-significant; $C . V$. $=$ coeff
followed by the same letter in the column do not differ by Scott-Knott's test at $5 \%$ probability.

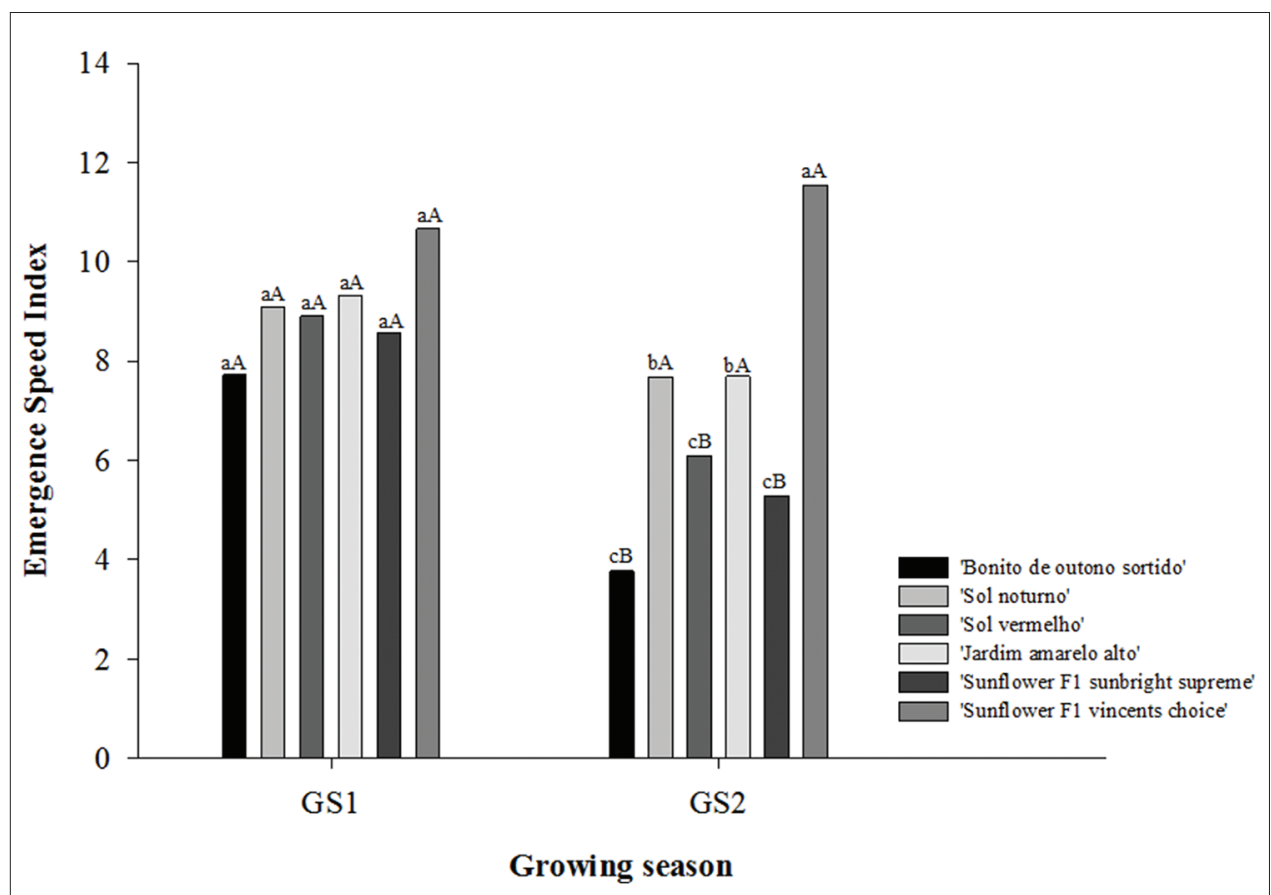

Fig 1. Emergence speed index (ESI) of ornamental sunflower cultivars and two growing seasons. Means with lowercase letters compare between cultivars and with capital letters compare between growing season. Means followed by the same letter, both between cultivars and growing season did not differ by Scott-Knott's test at $5 \%$ probability. 
visually presented greater uniformity at field. Considering each cultivars, 'Sol noturno', 'Jardim amarelo alto' and 'Sunflower F1 vincents choice' reacted in a similar way on both growing seasons and 'Bonito de outono sortido', 'Sol vermelho' and 'Sunflower F1 sunbright supreme' provided significant rates when sown in GS1, being 47.5\%, 31.57\% and $38.27 \%$, respectively, faster than in GS2, probably related to the higher temperatures (Table 1), that stimulate initial seedling growth. These results, in general, were lower than those reported by Barros and Rossetto (2009) when different seeds lots of sunflower 'Catissol' (13.31 to 16.54) were evaluated, but are closed to those verified by Rocha et al. (2015) for the 'Catissol 01', whose ESI values ranged from 9.0 to 12.0. According to Khalifa et al. (2000), the germination of sunflower seeds takes relative less time under high temperature and this can result in a shortly cycle.

\section{Growth and flowering evaluation}

The analysis of variance revealed that plant height, stem diameter, number of leaves and internal inflorescence diameter were significantly affected by the sunflower cultivars and growing season with no interaction between the sources. This indicates for these variables that cultivars achieved similar performance independently of the growing season. In particular, external inflorescence diameter was significantly affected by the interaction of sunflower cultivars and growing season (Table 5).

Regarding the sunflower cultivars (Table 5) it was found that 'Bonito de outono sortido' presented the highest value for plant height but without significant difference from 'Sol noturno', 'Sol vermelho' and 'Sunflower F1 Vincents Choice'. The lower size was recorded for 'Sunflower F1 sunbright supreme' which did not differ from 'Jardim amarelo alto'.

The Brazilian Institute of Floriculture (Ibraflor, 2016) based on marketing standard establishes that ornamental sunflower stems for cutting must have length ranging from 50.0 to $90.0 \mathrm{~cm}$. When considering this criterion, it was observed that all the cultivars presented plant height that allow harvesting stems with lengths according to the established rules. A larger stem also could mean higher carbohydrates content that contributes to greater transport resistance and longer post-harvest durability, according to Rodrigues et al. (2012). Higher plants also offer greater possibilities to use sunflower in floral art and arrangements, thus the commercial advantage would be greater (Andrade et al., 2012). However, heights above $200 \mathrm{~cm}$ for ornamental sunflower may difficult the crop management and plants could be suffering damages such as lodging, when the winds are intense (Curti et al., 2012).

There was a strongly positive correlation between plant height and stem diameter $\left(\mathrm{r}=0.76^{* *}\right)$ which could be observed especially for 'Bonito de outono sortido', 'Sol noturno' and 'Sol vermelho' that presented the highest plants and also the largest diameter. The opposite was verified for the smaller cultivars which showed thinner stems (Table 5), with exception for 'Sunflower F1 Vicents choice' that was similar in height to the taller plants and diameter with those lower values, respectively. The trade patterns for cut sunflower requires a stem diameter with a minimum of $8.0 \mathrm{~mm}$ for 50,60 and $70 \mathrm{~cm}$ lengths and a minimum of $11.0 \mathrm{~mm}$ for stems whose size varies from 80.0 to $90.0 \mathrm{~cm}$ (Ibraflor, 2016). It is desirable the correlation between stem diameter and plant high to support the inflorescence, mainly when the diameter of the capitulum are larger (Heldwein et al, 2014). The significant linear relationship between plant height and stem diameter provide good evidence that taller plants would require thicker stems to keep plants safely in the field (Hassan et al., 2005).

\begin{tabular}{|c|c|c|c|c|c|}
\hline Source of variation & $\mathrm{H}(\mathrm{cm})$ & $\mathrm{SD}(\mathrm{mm})$ & NL & IID (mm) & EID (mm) \\
\hline Blocks & $0.24^{\mathrm{ns}}$ & $0.66^{\mathrm{ns}}$ & $0.90^{\text {ns }}$ & $0.60^{\text {ns }}$ & $0.79^{\text {ns }}$ \\
\hline Cultivars (C) & $11.40^{* *}$ & 9.79 ** & $11.67^{\star *}$ & $8.10^{\star *}$ & $13.11^{* *}$ \\
\hline 'Bonito de outono sortido' & $138.43^{a}$ & $18.04^{\mathrm{a}}$ & $26.31^{a}$ & $29.30^{\mathrm{b}}$ & $50.90^{c}$ \\
\hline 'Sol noturno' & $134.22^{a}$ & $16.39^{b}$ & $26.29^{a}$ & $42.37^{b}$ & $64.67^{\circ}$ \\
\hline 'Sol vermelho' & $129.66^{a}$ & $15.90^{b}$ & $23.49^{b}$ & $60.07^{a}$ & $105.49^{b}$ \\
\hline 'Jardim amarelo alto' & $105.83^{b}$ & $13.39^{c}$ & $19.06^{c}$ & $43.27^{b}$ & $66.40^{\circ}$ \\
\hline 'Sunflower F1 sunbright supreme' & $99.90^{\mathrm{b}}$ & $15.09^{c}$ & $22.66^{\mathrm{b}}$ & $26.05^{b}$ & $49.43^{c}$ \\
\hline 'Sunflower F1 vincents choice' & $122.95^{a}$ & $14.45^{\circ}$ & $22.62^{\mathrm{b}}$ & $75.05^{\mathrm{a}}$ & $134.57^{\mathrm{a}}$ \\
\hline C.V. $(\%)(C)$ & 10.78 & 9.42 & 9.59 & 40.25 & 33.9 \\
\hline Growing Season (GS) & $37.64^{\star *}$ & $85.07^{* *}$ & $65.28^{* *}$ & $6.04^{*}$ & $16.39^{* *}$ \\
\hline GS1 & $110.61^{b}$ & $13.75^{\mathrm{b}}$ & $21.59^{b}$ & $42.11^{\mathrm{b}}$ & $66.08^{b}$ \\
\hline GS2 & $133.05^{a}$ & $17.34^{\mathrm{a}}$ & $25.22^{\mathrm{a}}$ & $49.92^{\mathrm{a}}$ & $91.07^{\mathrm{a}}$ \\
\hline C.V. (\%) (GS) & 10.4 & 8.67 & 6.64 & 23.9 & 27.22 \\
\hline Interaction C x GS & $1.63^{\text {ns }}$ & $2.20^{\text {ns }}$ & $1.62^{\text {ns }}$ & $2.19^{\text {ns }}$ & $5.60^{\star *}$ \\
\hline
\end{tabular}


Regarding the number of leaves, 'Bonito de outono sortido' and 'Sol noturno' showed significant higher averages (26.31 and 26.29, respectively) (Table 5), probably because they are the highest plants and also because they branched from the base resulting in more leaves. Our study revealed a strongly correlation between number of leaves with stem diameter $\left(\mathrm{r}=0.72^{* *}\right)$ and plant height $\left(0.71^{* *}\right)$. Tekelwold et al. (2000) reported that taller plants supported many leaves and a high number of leaves is desirable, consequently could increase total biomass through increased carbon fixation that can be ultimately partitioned. Simões et al. (2018) realized a study with 21 sunflowers varieties also in semiarid conditions and recorded for number of leaves values varying from 22.9 to 31.1. They attribute the differences to the characteristics of each cultivar and local climatic conditions, especially temperature.

In relation to flowering characteristics, 'Sunflower F1 vincents choice and 'Sol vermelho' presented significantly the largest internal inflorescence diameters and 'Jardim amarelo alto', 'Sol noturno', 'Bonito de outono sortido' and 'Sunflower F1 sunbright supreme' showed the lowest averages without, however, a difference between the cultivars (Table 5).

Considering the interaction between cultivars and growing seasons for external inflorescence diameter, the 'Sunflower F1 vincents choice' were significantly higher (144.03 mm) from all other cultivars when cultivated in GS1. In GS2,
'Sol vermelho' (150.06 mm) besides to 'Sunflower F1 vincents choice' $(125.11 \mathrm{~mm})$ presented the highest values. Considering each cultivar, only 'Sol Vermelho' were significantly affected when cultivated in GS2, with an increase of $146,3 \%$ comparing to when cultivated in GS1 (Fig. 2).

The inflorescence diameter associated with plant height and stem diameter is one of the main parameters for sunflower marketing. The ornamental sunflower cultivars were improved in order to obtain smaller capitulum sizes compared to the cultivars for oil extraction (Curti et al., 2012). Santos et al. (2016) argue that stems with larger inflorescences are more widely accepted and more appreciated in the market. Ibraflor (2016) establishes that, for sale, sunflower inflorescence with open flowers must have the minimum diameter of $60.0 \mathrm{~mm}$ for plants with $50.0 \mathrm{~cm}, 60.0 \mathrm{~cm}$ and $70.0 \mathrm{~cm}$ in length; and for stems with $80.0 \mathrm{~cm}$ and $90.0 \mathrm{~cm}$ in length, the minimum diameter should be $75.0 \mathrm{~mm}$. The ideal size for diameter is still not a consensus because nowadays the predominantly matters for consumers is the exuberance of colours and forms they present (Curti et al., 2012).

In a general way, the observed differences among cultivars might be attributed to intrinsic genetic characteristics of each one and the most characters are genetically controlled (Santos and Granjeiro, 2013). However, environmental conditions could modify this genetic potential (Pillai et al., 995).

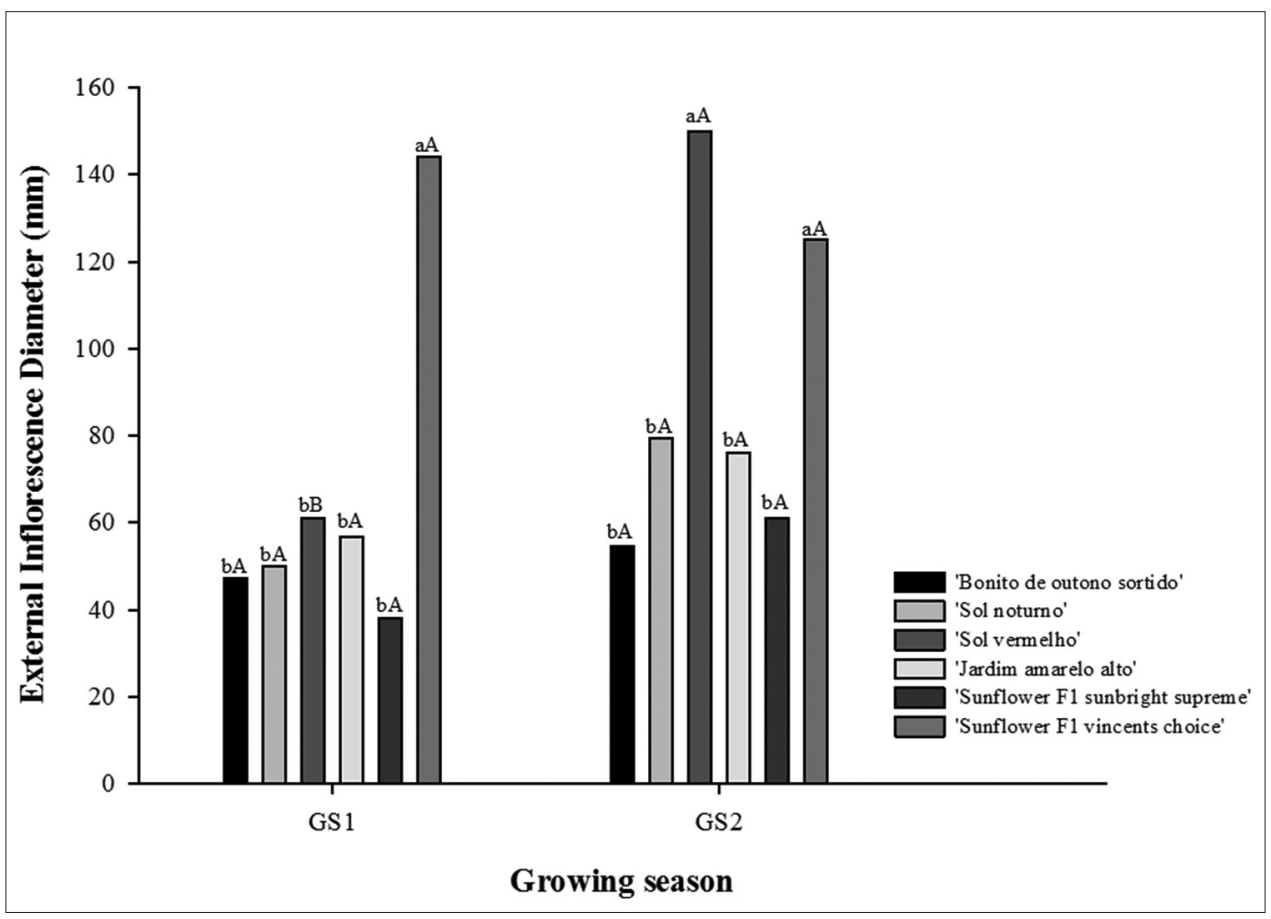

Fig 2. External inflorescence diameter (EID) of ornamental sunflower cultivars and two growing seasons. Means with lowercase letters compare between cultivars and with capital letters compare between growing seasons. Means followed by the same letter, both between cultivars and growing seasons, do not differ by Scott-Knott's test at $5 \%$ probability. 
Analyzing growing season effects on sunflower growth parameters, there was observed that although the specie is mentioned as rustic with wide climatic adaptability (Balalić et al., 2012), the cultivars developed for ornamental purposes seems to be affected by the environmental conditions. When the cultivars were planted in GS2, there were observed significant effect (Table 5) on plant height, stem diameter, number of leaves and internal inflorescence diameter with an increase in relation to GS1 of $20.3 \%$, $26.1 \%, 16.8 \%$ and $18.6 \%$, respectively.

Crop growth variables as air temperature, solar radiation and rainfall can limit growth and yield (Aguirrezábal et al., 2003). There is no consensus of the optimum temperature for sunflower growing and development, varying from $18-23^{\circ} \mathrm{C}$ (Gill et al., 2003) and $26-29^{\circ} \mathrm{C}$ (Rondanini et al., 2006). Considering this information it is remarkable the adaptability of the cultivars to height temperatures used in this study (Table 1), but on the other hand, even because the production of flower stems occurred, it was noticed that the differences in temperature values from one growing season to another affected the performance of the crop (Table 1). Air temperature plays an important role in crop development (Kaleem et al., 2009) and changes in minimum temperature are importante to determine the phenology of crops (Hatfield et al., 2011; Nasim et al., 2016).

\section{CONCLUSIONS}

The results of the present study indicated that is possible the growth of ornamental sunflower for cut flower in semiarid climate conditions, obtaining stems and inflorescences diameter with quality and meeting the commercial standards. When considering the set of evaluations carried out, two cultivars presented higher agronomic performance and, therefore, are considered more acclimatized to the region: 'Sol vermelho' indicated for cultivation in growing seasons with mild temperatures and 'Sunflower F1 vincents choice', recommended for both growing seasons with mild climatic and in warmer conditions. It should be noted that although the achieved results were satisfactory and fundamental to subsidize the implantation of the crop in the study region, there is still a need for more research covering all other cultivars of this study and other seasonal variations of the year, in order to reduce the risks caused by climate fluctuations, to maintain the regularity of production and avoid seasonality, thus ensuring the supply of products throughout the year.

\section{ACKNOWLEDGMENTS}

The authors thank National Council for Scientific and Technological Development (CNPq) and Foundation of Science and Technology Support of Pernambuco (FACEPE) by the financial support.

\section{Autor's contributions}

S.D.P.S.: Field experiments, data analysis and write the manuscript. G.P.S.: Collaboration in field experiments and manuscript translation. T.S.O and R.R.L.: Contribution in field experiments. A.R.M.C.: Supervision and manuscript review. M.Z.B.C.: Experimental design, supervision and manuscript review.

\section{REFERENCES}

Aguirrezábal, L. A., Y. Lavaud, G. A. Dosio, N. G. Izquierdo, F. H. Andrade and L. M. González. 2003. Intercepted solar radiation during seed filling determines sunflower weight per seed and oil concentration. Crop Sci. 43: 152-161.

Alvares, C. A., J. L. Stape, P. C. Sentelhas, J. L. M. Gonçalves and G. Sparovek. 2014. Köppen's climate classification map for Brazil. Meteorol. Zeitschrift. 22: 711-728.

Andrade, L. O., H. R. Gheyi, R. G. Nobre, N. S. Dias and E. C. S. Nascimento. 2012. Qualidade de flores de girassóis ornamentais irrigados com águas residuária e de abastecimento. Idesia. 30: $19-27$.

Balalić, I., M. Zorić, G. Branković, S. Terzić and J. Crnobarac. 2012. Interpretation of hybrid $\times$ sowing date interaction for oil content and oil yield in sunflower. Field Crop Res. 137: 70-77.

Barros, C. S. and C. A. V. Rossetto. 2009. Teste de germinação sob condições de restrição hídrica para avaliar o vigor de sementes de girassol. Cienc. Rur. 39: 2621-2624.

Beard, B. H. and S. Geng. 1982. Interrelationships of morphological and economic characters of sunflower. Crop Sci. 22: 817-822.

Berglund, D. R. 2007. Sunflower Production. North Dakota State University Extension Service, Fargo, ND, Bulletin 25.

Bewley, J. D., K. J. Bradford, H. W. M. Hilhorst and H. Nonogaki. 2013. Seeds: Physiology of Development, Germination and Dormancy. $3^{\text {rd }}$ ed. Springer, New York.

Brasil. Ministério da Agricultura, Pecuária e Abastecimento. 2009. Regras Para Análise de Sementes. Secretaria de Defesa Agropecuária, Brasília, DF.

Coutinho, P. W. R., R. F. B. Sousa and C. Y. Tsutsumi. 2015. Métodos de melhoramento genético no girassol. Nucleus. 12: 119-128.

Curti, G. L., T. N. Martin, M. L. Ferronato and G. Benin. 2012. Girassol ornamental: Caracterização, pós-colheita e escala de senescência. Rev. Cienc. Agra. 35: 240-250.

Gill, S., E. Dutky, R. Balge, W. MacLachlan and S. Klick. 2003. Producing Anual Sunflowers as Cut Flowers. Fact Sheet, 686.

Hassan, F.U., Q. Ghulam and R. A. Ahmad. 2005. Growth and development of sunflowers in response to seasonal variations. Helia. 42: 159-166.

Hatfield, J. L., K. J. Boote, B. A. Kimball, L. H. Ziska, R. C. Izaurralde, D. Ort, A. M. Thomson and D. W. Wolfe. 2011. Climate impacts on agriculture: Implications for crop production. Agron. J. 103: 351-370.

Heldwein, A. B., L. H. Loose, D. D. P. Lucas, F. D. Hinnah, M. P. Bortoluzzi and I. C. Maldaner. 2014. Yield and growth characteristics of sunflower sown from August to February in Santa Maria, RS. R. Bras. Agríc. Ambiental. 18: 908-913.

Ibraflor. Instituto Brasileiro de Floricultura. 2016. Padrão de Qualidade: 
Girassol Corte. Available from: http://www.ibraflor.com/ publicacoes/vw.php?cod=76. [Last accessed on 2016 Sep 24].

Inmet. InstitutoNacional de Meteorologia.2016. Normais Climatológicas do Brasil 1961-1990. Available from: http://www.inmet. gov.br/portal/index.php?r=clima/normaisclimatologicas. [Last accessed on 2016 Feb 22].

Izquierdo, N. G., L. A. N. Aguirrezábal, F. H. Andrade, C. Geroudet, O. Valentinuz and M. Pereyra Iraola. 2009. Intercepted solar radiation affects oil fatty acid composition in crop species. Field Crop Res. 114: 66-74.

Junqueira, A. H. and M. S. O. Peetz. 2017. Brazilian consumption of flowers and ornamental plants: Habits, practices and trends. Ornam. Hortic. 23: 178-184.

Khalifa, F. M., A. A. Schnetter and E. I. El-Tayeb. 2000. Temperaturegermination response of sunflower (Helianthus annuus L.) genotypes. Helia. 23: 97-104.

Kaleem, S., F.U. Hassan and A. Saleem. 2009. Influence of environmental variations on physiological attributes of sunflower. Afr. J. Biotechnol. 8: 3531-3539.

Maguire, J. D. 1962. Speed of germination-aid in selection and evolution for seedling emergence and vigor. Crop Sci. 2: 176177.

Nascimento, A. M. P., S. N. Reis, F. C. Nery, I. C. S. Curvelo, T. C. Taques and E. F. A. Almeida. 2016. Influence of color shading nets on ornamental sunflower development. Ornam. Hortic. 22: 101-106.

Nasim, W., H. Belhouchette, A. Ahmad, M.H. Rahman, K. Jabran, K. Ullah, S. Fahad, M. Shakeel and G. Hoogenboom. 2016. Modelling climate change impacts and adaptation strategies for sunflower in Punjab-Pakistan. Outlook Agric. 45: 39-45.

Newman, S. E. 2011. Floriculture. Encyclopedia of Environmental Health, Elsevier, Burlington. pp. 756-768.

Papatheohari, Y., I. S. Travlos, P. Papastylianou, I. G. Argyrokastritis and D. J. Bilalis. 2016. Growth and yield of three sunflower hybrids cultivated for two years under mediterranean conditions. Emir. J. Food Agric., 28: 136-142.

Pillai, M. A., P. Ramalingam, C. S. Sridharan, S. Murugan and C. Vanniarajan. 1995. Stability analysis for seed yield and its components in sunflower hybrids. Ann. Agric. Res. 16: 409-412.

Porto, W. S., C. G. P. Carvalho and R. J. B. Pinto. 2007. Adaptabilidade e estabilidade como critérios para seleção de genótipos de girassol. Pesq. Agropec. Bras. 42: 491-499.

Ribeiro, A. C., P. T. G. Guimarães and V. V. H. Alvarez (Ed.)., 1999. Recomendação Para o Uso de Corretivos e Fertilizantes em Minas Gerais: 5 Aproximação. Comissão de Fertilidade do Solo do Estado de Minas Gerais, Viçosa, MG.

Rocha, C. R. M., V. N. Silva and S. M. Cicero. 2015. Avaliação do vigor de sementes de girassol por meio de análise de imagem de plântulas. Cienc. Rur. 35: 970-976.

Rodrigues, E. J. R., K. F. L. Pivetta, R. M. M.de Castilho, C. F. M. Mattiuz, G. S. Batista and J. A. S. Grossi. 2012. Girassol. In: Paiva, P. D. O. and E. F. A. Almeida. (Eds.), Produção de Flores de Corte. UFLA, Lavras, MG, pp. 403-440.

Rondanini, D., A. Mantese, R. Savin and A. J.Hall, 2006. Responses of sunflower yield and grain quality to alternating day/night high temperature regimes during grain filling: effects of timing, duration and intensity of exposure to stress. Field Crops Res. 96: 48-62.

Santos, J. F. and J. I. T. Granjeiro. 2013. Desempenho de cultivares de girassol na microrregião de Campina Grande, PB. Tecnol. Cienc. Agropec. 7: 41-47.

Santos, M. H. L. C., C. C. S. Lopes, E. H. F. Santos, M. W. Silva and A. K. L. Pais. 2016. Cultivo de girassol ornamental sob telas de sombreamento no Vale do São Francisco. Sodebras. 11: 93-95.

Silva, F. A. S. and C. A. V. Azevedo. 2016. The Assistat Software Version 7.7 and its use in the analysis of experimental data. Afr. J. Agric. Res. 11: 3733-3740.

Soil Survey Staff. 2014. Keys to Soil Taxonomy. $12^{\text {th }}$ ed. United States Department of Agriculture, Natural Resources Conservation Service, Washington, DC.

Simões, W. L., M. A. Drumond, A. R. Oliveira, S. L. Gonçalves and M. J. M. Guimarães. 2018. Morphophysiological and productive responses of sunflower varieties to irrigation. Rev. Caatinga. 31: 143-150.

Tekelwold, A., H. Jayarmaiah and B. N. Jagadesh. 2000. Correlation and path analysis of physio-morphological characters of sunflower (Helianthus annuus L.) as related to breeding method. Helia. 23: 105-114.

Zaidi, H. S., M. A. A. Bukhsh, E. H. Siddiqi and M. Ishaque. 2012. Agronomic characteristics of spring planted sunflower hybrids as influenced by potassium application. J. Anim. Plant Sci. 22: 148153. 